\title{
Turf Performance and Physiological Responses of Native Poa Species to Summer Stress in Northeast China
}

Yajun Chen ${ }^{1}$, Zhixin Guo ${ }^{1}$, Lili Dong ${ }^{1}$, Zhenxuan Fu ${ }^{1}$, Qianjiao Zheng ${ }^{1}$, Gaoyun Zhang ${ }^{1}$, Ligang Qin ${ }^{2}$, Xiaoyang Sun ${ }^{1}$, Zhenjie Shi ${ }^{1}$, Shah Fahad. ${ }^{3}$, Fuchun Xie ${ }^{\text {Corresp., } 1}$, Shah Saud ${ }^{\text {Corresp. } 1}$

${ }^{1}$ College of Horticulture and Landscaping, Northeast Agricultural University, Harbin, Heilongjiang, China

College of Animal Science and Technology, Northeast Agricultural University, Harbin, Heilongjiang, China

3 Department of Agronomy, University of Haripur, Khyber Pakhtunkhwa, pakistan

Corresponding Authors: Fuchun Xie, Shah Saud

Email address: xfc204309@163.com, saudhort@gmail.com

Rapid rise in temperature in summer causes severe injury to cool-season turfgrass of both native species and introduced ones in Heilongjiang of Northeast China. The objectives of this study were to compare physiological responses to seasonal heat stresses and turf performances between native and introduced commercial Poa accessions. Three Chinese native Poa species (ie. P. pratensis, $P$. sibirica and $P$. sphondylodes) and three USA Kentucky bluegrass cultivars (ie. 'Midnight', 'Moonlight' and 'BlueChip') were evaluated under field conditions in 2017 and 2018. All accessions showed unique characteristics and considerable seasonal differences in response to temperatures. However, performances over all accessions were largely similar in early spring and autumn. In summer, native $P$. pratensis performed similar to 'Midnight', 'Moonlight' or 'BlueChip', with respect to such traits or parameters as quality, coverage, color intensity, growth rate, osmolytes, ROS and anti-oxidant production. Native $P$. pratensis could be used as a new turf resource for further improvement and application under the specific climatic conditions in Heilongjiang; native $P$. sphondylodes may be used in repairing damaged environments or for alternative seasonal greenness. 


\section{Turf Performance and Physiological Responses of Native Poa Species to}

\section{Summer Stress in Northeast China}

3 Yajun Chen ${ }^{1}$, Zhixin Guo ${ }^{1}$, Lili Dong ${ }^{1}$, Zhenxuan Fu ${ }^{1}$, Qianjiao Zheng ${ }^{1}$, Gaoyun Zhang ${ }^{1}$, Ligang

4 Qinn $^{2}$, Xiaoyang Sun ${ }^{1}$, Zhenjie Shi ${ }^{1}$, Fahad Shah ${ }^{3}$, Fuchun Xie ${ }^{1 *}$, Saud Shah ${ }^{1 *}$

$5 \quad{ }^{1}$ College of Horticulture, Northeast Agricultural University, Heilongjiang, China,

$6{ }^{2}$ College of Animal Science and Technology, Northeast Agricultural University, Heilongiang, 7 China

$8 \quad{ }^{3}$ Department of Agronomy, University of Haripur, Khyber Pakhtunkhwa, Pakistan

9 Co-corresponding authors: Fuchun Xie, Saud Shah

10 E-mail: xfc204309@163.com; saudhort@gmail.com

\section{ABSTRACT}

Rapid rise in temperature in summer causes severe injury to cool-season turfgrass of both native species and introduced ones in Heilongjiang of Northeast China. The objectives of this study were to compare physiological responses to seasonal heat stresses and turf performances between native and introduced commercial Poa accessions. Three Chinese native Poa species (ie. P. pratensis, $P$. sibirica and $P$. sphondylodes) and three USA Kentucky bluegrass cultivars (ie. 'Midnight', 'Moonlight' and 'BlueChip') were evaluated under field conditions in 2017 and 2018. All accessions showed unique characteristics and considerable seasonal differences in response to temperatures. However, performances over all accessions were largely similar in early spring and autumn. In summer, native $P$. pratensis performed similar to 'Midnight', 'Moonlight' or 'BlueChip', with respect to such traits or parameters as quality, coverage, color intensity, growth rate, osmolytes, ROS and anti-oxidant production. Native $P$. pratensis could be 
used as a new turf resource for further improvement and application under the specific climatic conditions in Heilongjiang; native $P$. sphondylodes may be used in repairing damaged environments or for alternative seasonal greenness.

\section{INTRODUCTION}

A diverse germplasm of the genus Poa distributes worldwide in cold and Northern temperate zone, and even high-elevation-tropical regions, where more than 500 species are available in a wide range of habitats (Soreng, 1990). Some 105 Poa species exist in China, which are mainly distributed in those cold, Northern regions and areas including Qinghai-Tibet plateau (Chen et al., 2008). Some species of the genus possess excellent turf attributes, such as fine texture, pleasing color and playability, which are widely exploited and used in sports, public and commercial landscapes, and home lawns (Chen et al., 2019). The abundance Poa resources in China could potentially be developed for turfgrass and/or for improving resistance to environmental stress. However, there has been no exploitation of theses Poa species in Heilongjiang of China yet.

The first Kentucky bluegrass cultivar 'Merion' was released in 1947 by the United States Golf Association (Meyer, 1982). Since then, Poa breeding activities has been launched in the USA and some European countries, where extensive germplasm collection, subsequent screening and identification morphology, stress physiology and molecular bases, and promoting of elite materials were undertaken (Saud et al., 2014, 2020; Johnson et al., 2002; Fan et al., 2020). To date, commercial turf-type species in the genus of Poa mainly involve Kentucky bluegrass $(P$. pratensis L.), Canada bluegrass ( $P$. compressa L.), perennial biotype of annual bluegrass $(P$. annua spp. reptans), and/or rough bluegrass (P. trivialis L.), with Kentucky bluegrass being the most widely used one. Kentucky bluegrass entries are classified into several ecotypes, on the basis of morphology, genetics and resistance to stresses, they include 'Compact', 'Bellevue', 
46 'Mid-Atlantic', 'BVMG', 'Shamrock' and 'America' (Honig et al., 2012, 2018). Some cultivars

47 were introduced to China in the 1980s, for example, 'Midnight', which has been the most widely

48 used one in Northeast China.

49 Kentucky bluegrass belongs to a monophyletic genus according to geographic evidences

50 (Hartley, 1961). It has a high and variable polyploidy, its chromosome numbers range from $5 \times$

51 to $15 \times$, with a base number of seven (Casler \& Duncan, 2003, Bushman et al., 2018). However,

52 the number of chromosomes is reported to be of limited value in characterizing Kentucky

53 bluegrass cultivars (Speckmann \& Van Dijk, 1972), as genome duplication suggests a link with

54 environmental conditions. Plant polyploids often thrive in harsh and disturbed habitats by

55 alteration of tissue structures and morphological characteristics. Stress response is an important

56 factor in the establishment and success of polyploidy (Van de Peer et al., 2021), indicating both

57 the flexibility and the potentiality of Poa germplasm improvement in response to different

58 environmental stresses.

59 Species in genus $P o a$ are cool-season grasses, requiring optimum temperatures between $15^{\circ} \mathrm{C}$

60 and $24^{\circ} \mathrm{C}$ (Turgeon, 2008). Air and/or soil temperatures often reach supra-optimal levels during

61 summer period, which limit shoot and root growth of cool-season grasses leading to plant

62 dormancy or even death (Fry \& Huang, 2004). Although located in Northeast temperate zone,

63 Heilongjiang province of China is often influenced by monsoon and atmospheric circulation,

64 where heat injury events occur frequently during the seasons of turfgrass growing, especially in

65 the months of June to August. During this period, some introduced cultivars suffer serious

66 damages on turf. Exploitation and utilization of native, wild-type Poa species available in

67 Heilongjiang of China and development for resistance to summer heat stress would be effective

68 measures to improve turfgrass quality. Although differential heat resistance strategies have been 
69 studied extensively in turfgrass species (Li et al., 2014; Zhang et al., 2017; Wang et al., 2018),

70 limited research has been conducted on evaluating heat resistance of native Poa species as well

71 as their comparative heat performances.

72 Studying turf performances and physiological heat tolerance characteristics in native Poa can 73 generate valid data and information to help with planning a plant breeding program on turfgrass

74 improvement. It was extremely hot during June and August in 2017 and 2018 in Heilongjiang,

75 which caused severe heat stress on Kentucky bluegrass turf. Although not what we expected, this

76 event of summer heat stress provided an opportunity for native Poa species to be assesses for turf

77 use. In this research, three native, wild-type Poa species (ie. P. pratensis, $P$. sibirica and $P$.

78 sphondylodes) collected from Heilongjiang province were evaluated and compared with three

79 introduced Kentucky bluegrass cultivars (ie. 'Midnight', 'Moonlight' and 'BlueChip'). We

80 examined the chromosome numbers for each species and cultivars to elucidate their genetic

81 differences at the cytological level prior to the field experiment. Our hypothesis is that if these

82 selected Poa accessions native to Heilongjiang have better summer heat tolerance than

83 introduced cultivars, the native ones could then be used as turfgrass to be adopted locally. The

84 objectives of this study were: (i) to compare seasonal turf performance and physiological heat

85 responses between native, wild-type Poa species and commercial Kentucky bluegrass cultivars;

86 and (ii) to determine differential heat resistance characteristics associated with variabilities of

87 these tested accessions.

88 Materials and Methods

89 Experimental site and turf trials

90 The experiment was conducted over two years (20172018) on a black loam soil at the Northeast

91 Agricultural University Horticulture Station in Harbin, Heilongjiang province of Northeast China 
$92\left(45^{\circ} 43^{\prime} 55^{\prime \prime} \mathrm{N}, 126^{\circ} 43^{\prime} 21^{\prime \prime} \mathrm{E}\right)$. The research area has a typical cold temperate, continental monsoon

93 climate: hot and rainy summer, and cold and dry winter, with tropical cyclones in summer and

94 autumn seasons. Mean temperatures and precipitation during the study period are listed in Fig. 1.

95 Soil organic matter was $24.6 \mathrm{~g} / \mathrm{kg}$ with a $\mathrm{pH}$ in water of 7.0. Turf was established in May 2016,

96 seeded at $15 \mathrm{~g} / \mathrm{m}^{2}$ for complete grow-in to produce a mature turf as the trial was established.

97 Native species of P. pratensis, P. sibirica and P. sphondylodes (Abbreviated as Hpp, Hpsi and 98 Hpsp, respectively) from Heilongiiang were used as materials, along with three USA commercial 99 Kentucky bluegrass cultivars 'Midnight', 'Moonlight' and 'BlueChip' (Abbreviated as Mid, Moo 100 and Blu, respectively). Natural habitats of 'Hpp', 'Hpsi' and 'Hpsp' are around 45'46'38"N, $1011^{\circ} 126^{\circ} 38^{\prime} 54^{\prime \prime} \mathrm{E}, 45^{\circ} 49^{\prime} 22^{\prime \prime} \mathrm{N}, 127^{\circ} 52^{\prime} 17^{\prime \prime} \mathrm{E}$ and $46^{\circ} 16^{\prime} 48^{\prime \prime} \mathrm{N}, 124^{\circ} 35^{\prime} 54^{\prime \prime} \mathrm{E}$, respectively. Average turf 102 quality (TQ) of 'Mid', 'Moo' and 'Blu' is 6.4, 5.5 and 3.6 reported earlier by Shortell et al. 103 (2004). Cytogenetic analyses by FISH indicated differences in chromosomes and ploidy levels of 104 the three native Poa species (Fig. 2).

105 The field trial was conducted using a randomized complete block design with four replicates, 106 with each plot measured $1.2 \mathrm{~m}$ wide by $5 \mathrm{~m}$. During the growing seasons, granular and liquid 107 fertilizers were supplied at $2 \mathrm{~g} \mathrm{~N} / \mathrm{m}^{2}$ per month. Turfgrass was maintained to a height of $4 \mathrm{~cm}$ tall 108 above ground.

109 Assessments and measurements

110 Seasonal measurements were made monthly from May to October in 2017 and 2018. Turf 111 performance was evaluated under natural field conditions, while physiological indices were 112 performed in laboratory on field-collected samples. 


\section{Turf quality, color and turf coverage}

115 Turf quality was rated from 1 to 9 , where 1 is very poor, 9 is excellent. Turf color was scaled

116 from 1 to 9 , where 1 is completely faded, 9 is the most freshly green. A score of 5 is the lowest

117 acceptable value for both turf quality and color. Turf coverage as a percentage of plot areas was

118 determined monthly.

\section{Turfgrass growth rate and tiller numbers}

120 The height of turf was recorded on $6^{\text {th }}, 7^{\text {th }}, 16^{\text {th }}, 17^{\text {th }}, 26^{\text {th }}, 27^{\text {th }}$ of each month throughout the

121 experimental period. The height of grass canopy was measured at 10 sites per plot using a digital

122 caliper (Guanglu, China); growth rate was calculated as the average of the 10 daily height

123 increment $(\mathrm{mm})$ from $4 \mathrm{~cm}$ to which it was mowed, two days earlier. Tiller numbers were

124 counted at 6 sites per plot monthly and expressed as numbers of tillers per square centimeters.

\section{Chromosome}

Chromosome numbers in cells of root tips were detected and counted using the fluorescence in situ hybridization (FISH) method (Said et al., 2021). Briefly, 15 to $20 \mathrm{~mm}$ of the end of vigorously growing roots was excised using a scalpel and fixed in a fixative solution of ethanol: glacial acetic acid $=3: 1(\mathrm{v} / \mathrm{v})$ for $24 \mathrm{~h}$, then transferred to an enzyme mixture $(4 \%$ cellulase and $2 \%$ pectinase), hydrolyzed in a $37^{\circ} \mathrm{C}$ water bath, washed with water and fixed, and placed on a glass slide and then dispersed in $45 \%$ acetic acid. After drying with a fixative, those welldispersed slides were selected for FISH using 5S rDNA and 45S rDNA probes. Observations were finally performed with a fluorescence microscope (BX-61, Olympus, Japan), with images collected via a microscope camera (DS-Ri1, Nikon, Japan). 
137 Chlorophyll and osmotic regulating substance

138 Chlorophyll (Chl) was extracted by soaking $0.1 \mathrm{~g}$ of fresh leaves in $10 \mathrm{~mL}$ of dimethyl sulfoxide

139 for $72 \mathrm{~h}$ (Hiscox \& Israelstam, 1979); its absorbance (at $646 \mathrm{~nm}$ and $663 \mathrm{~nm}$ ) was recorded with 140 a Micro plate spectrophotometer (Epoch, BioTek, USA).

141 Content of total soluble protein (TSP) was measured with the method of coomassie brilliant, blue 142 G-250 (Bradford, 1976). Powders (2 g in wt) of fresh leaves with $6 \mathrm{ml}$ distilled water were 143 ground into homogenate, and stood in a centrifuge tube for $0.5-1.0 \mathrm{~h}$. Extractions $(0.1 \mathrm{ml})$ were 144 then centrifuged at $4,000 \times \mathrm{g}$ for $15 \mathrm{~min}$ at $4{ }^{\circ} \mathrm{C}$, finally, mixed with $\mathrm{G}-250(5 \mathrm{ml})$. Absorbance 145 was read at $646 \mathrm{~nm}$ and $663 \mathrm{~nm}$. The content of TSP was calculated according to the standard 146 curve.

147 Free proline (Pro) content of leaves was determined using the acid ninhydrin method as described by Abraham et al. (2010) with some modifications. Fresh leaves $(0.5 \mathrm{~g})$ were ground in $14910 \mathrm{ml}$ of $3 \%$ sulphosalicylic acid and centrifuged for $10 \mathrm{~min}$, supernatant $(2 \mathrm{~g})$ was added to 3 $\mathrm{ml}$ of freshly prepared acid-ninhydrin solution and $2 \mathrm{ml}$ of glacial acetic acid. The mixture was incubated at $90^{\circ} \mathrm{C}$ for $1 \mathrm{~h}$ and put in an ice bath to stop the reaction; and then, $5 \mathrm{ml}$ of toluene was added to the extract mixture and stood for $20 \mathrm{~min}$ at $25^{\circ} \mathrm{C}$ to separate toluene and water; finally, the toluene phase was collected to measure the absorbance at $520 \mathrm{~nm}$.

Total soluble sugar (TSS) was measured as described previously (Wei et al., 2016) with some modifications. A $0.5 \mathrm{~g}$ of powder of fresh leaf was homogenized in $5 \mathrm{ml}$ of $80 \%$ ethyl alcohol (v

$156 / \mathrm{v})$; the extraction was centrifuged at $6,000 \times \mathrm{g}$ for $15 \mathrm{~min}$ at $4^{\circ} \mathrm{C}$. The separated supernatant 157 was transferred to another test tube, with $12.5 \mathrm{ml}$ of $80 \%$ ethyl alcohol (v/ v) added. Then, $1 \mathrm{ml}$ 
158 of the reaction liquid and $1 \mathrm{ml}$ of $0.2 \%$ anthrone were mixed; the mixture was incubated at

$159100^{\circ} \mathrm{C}$ for $10 \mathrm{~min}$ and put in an ice bath for $5 \mathrm{~min}$ to stop the reaction. TSS content was

160 determined using a spectrophotometer at $620 \mathrm{~nm}$.

\section{Antioxidant enzymes activity and $\mathrm{O}_{2}{ }^{--}$content}

162 For the assay of antioxidant enzymes activity and level of superoxide anion content $\left(\mathrm{O}_{2}^{--}\right), 0.5 \mathrm{~g}$ 163 of fresh leaves was homogenized at $5-10{ }^{\circ} \mathrm{C}$ using $2 \mathrm{~mL}$ of $50 \mathrm{mM}$ phosphate extraction buffer $164(\mathrm{pH} 7.8)$ in an ice-cold mortar. The mixture was centrifuged at $12,000 \times \mathrm{g}$ for $15 \min$ at $4{ }^{\circ} \mathrm{C}$ to collect the supernatant for quantification of enzyme activities and superoxide anion $\left(\mathrm{O}_{2}{ }^{-}\right)$. The superoxide dismutase (SOD) activity was measured by recording the rate of p-nitro blue tetrazolium chloride (NBT) reduction in absorbance at $560 \mathrm{~nm}$ (Giannopolities and Rise, 1977). Superoxide anion content $\left(\mathrm{O}_{2}{ }^{--}\right)$was measured by the hydroxylamine oxidation method and the absorbance was read at $530 \mathrm{~nm}$ (Tian et al., 2003). The activity of peroxidases (POD) and catalase (CAT) were determined in absorbance at $240 \mathrm{~nm}$ and $470 \mathrm{~nm}$, respectively (Tian et al., 2003).

\section{Levels of glutathione (GSH), ascorbic acid (AsA), malondialdehyde (MDA) and $\mathrm{H}_{2} \mathrm{O}_{2}$}

173 For glutathione (GSH), ascorbic acid (AsA) and malondialdehyde (MDA) contents, $0.1 \mathrm{~g}$ of 174 fresh leaves was ground with $1 \mathrm{~mL}$ of $10 \%(\mathrm{w} / \mathrm{v})$ trichloroacetic acid (TCA), centrifuged at $17512,000 \times \mathrm{g}$ at $4{ }^{\circ} \mathrm{C}$ for $20 \mathrm{~min}$; then the supernatant was collected for assay. The content of AsA 176 was measured following the method of Guo et al. (2013). $4 \mathrm{ml}$ of $\mathrm{NaH}_{2} \mathrm{PO}_{4}, 0.4 \mathrm{ml}$ of $10 \%$ TCA, $1770.4 \mathrm{ml}$ of $44 \% \mathrm{H}_{3} \mathrm{PO}_{4}, 0.4 \mathrm{ml}$ of $4 \% 2,2$-Bipyridine, and $0.2 \mathrm{ml}$ of $3 \% \mathrm{FeCl}_{3}$ were added to 1 $178 \mathrm{ml}$ of supernatant. The mixture was heated at $37^{\circ} \mathrm{C}$ for $1 \mathrm{~h}$. Absorbance was measured at $525 \mathrm{~nm}$. 179 Content of GSH was determined according to the method of Griffith (1980), $1 \mathrm{ml}$ of the 180 supernatant was added with $2.4 \mathrm{ml}$ of $0.1 \mathrm{~mol} \mathrm{~L}^{-1}$ phosphate buffered saline $(\mathrm{pH} 7.7)$ and $0.2 \mathrm{ml}$ 
181 of $4 \mathrm{mmol} \mathrm{L}^{-1}$ 5, 5-dithiobium-(2-nitrobenzoic acid). Absorbance was determined at $412 \mathrm{~nm}$.

182 Content of MDA was determined by the thiobarbituric acid method (Ma et al., 2015), $2 \mathrm{ml}$ of the

183 supernatant was mixed with $2 \mathrm{ml}$ of $0.6 \% \mathrm{TBA}$, the mixture was then heated at $95{ }^{\circ} \mathrm{C}$ for $30 \mathrm{~min}$,

184 quickly cooled, and then centrifuged at $10,000 \times \mathrm{g}$ for $10 \mathrm{~min}$. Absorbance of the supernatant

185 was measured at $450 \mathrm{~nm}, 532 \mathrm{~nm}$, and $600 \mathrm{~nm}$ to calculate the MDA content. The procedure

186 outlined in the $\mathrm{H}_{2} \mathrm{O}_{2}$ Quantitative Assay Kit (BioVision, USA) was followed for the assay of

$187 \mathrm{H}_{2} \mathrm{O}_{2}$ content at $415 \mathrm{~nm}$.

\section{Statistical analysis}

189 Mean data over two years of 2017 and 2018 in projected turf performance and physiological

190 indices were analyzed using ANOVA (SPSS v 18.0, Inc., Chicago IL). The Fisher's protected

191 least significant difference (LSD) at $\mathrm{P}<0.05$ was used to detect if significant differences existed 192 among entries or among months in the experiment.

\section{RESULTS}

194 Turfgrass quality and color

195 Results of effects of seasonal temperature on turf quality (TQ) and color of the native and 196 introduced bluegrasses are presented in Table 1. TQ of 'Mid' was statistically superior 197 throughout the seasons but similar to that of native'Hpp' except during September.

TQ of 'Moo' was similar to that of 'Mid' during September and October. 'Blue' performed 199 similar to native 'Hpsi' throughout the growing seasons. During May, September and October, 200 the turf color of 'Hpsp' being darker green was significantly better to that of 'Moo', 'Blu' or 201 'Hpsi', but similar to that of 'Mid', 'Moo' and 'Hpp'. Whilst TQ was the poorest, compared with 202 other bluegrasses from June to September. During early spring seasons, the color of 'Hpsp' was 
203 significantly better than that of 'Hpsi' and 'Blu', but similar to that of 'Moo' and 'Blu' in

204 October. In summer, the color of 'Hpp' (8.0 in June, 7.5 in July, and 6.8 in August) was similar 205 to that of 'Mid' and 'Moo'.

\section{Turf coverage and growth rate}

207 Analysis of variance exhibited significant variabilities in turf coverage and growth rate among 208 accessions varying with changing temperatures (Table 2). Maximum turf coverage was observed 209 in 'Mid', it was however statistically similarto that in 'Moo' and 'Hpp'. Turf coverage observed 210 in 'Blu' was initially similar to that in 'Moo', 'Mid' and 'Hpp' in the month of May but was

211 lower than in 'Mid' in other subsequent months of the growing season. Although the turf 212 coverage of 'Hpsi' performed lower than the rest except 'Hpsp', that was still acceptable. The 213 lowest turf coverage was observed in 'Hpsp' from June to August. Generally, the turf coverage 214 reduced in summer and then increased in autumn. The highest growth rate was observed in 'Mid' 215 regardless of a rising seasonal temperature from early spring to summer, which was similar to 216 that in native 'Hpsi' except September. The growth rate measured in 'Hpp' was similar to that in

217 'Moo' through the growing season, and significantly lower than that in 'Mid' and 'Hpsi' but 218 generally higher than that in 'Blu'. 'Hpsp' had the lowest growth rate during spring and autumn.

219 Number of tillers

220 The number of tillers were significantly different among entries in both years Table 3).

221 Maximum tillers were observed in 'Mid' regardless of changes of the seasonal temperatures. The 222 tiller number of 'Hpp' was statistically similar to that of 'Mid' and 'Moo' for the whole growing 223 period although slightly different in May and September. A similar seasonal trend in tillers 
224 numbers was observed in 'Hpsi' during both years, however, its tiller numbers were apparently

225 lower than those of others except 'Hpsp' which had the lowest tillers numbers among all entries.

\section{$2263.4 \mathrm{H}_{2} \mathrm{O}_{2}, \mathrm{O}_{2}{ }^{--}, \mathrm{Chl}$ and $\mathrm{MDA}$ contents}

$227 \mathrm{H}_{2} \mathrm{O}_{2}, \mathrm{O}_{2}{ }^{-}, \mathrm{Chl}$ and MDA contents among the turfgrass entries showed significant differences

228 (Figure $3 \mathrm{~A}, \mathrm{~B}, \mathrm{C}, \mathrm{D})$. These parameters were observed to increase with rising temperatures from

229 spring to summer, reaching a peak in August and then declining from October. Overall, $\mathrm{H}_{2} \mathrm{O}_{2}$

230 and $\mathrm{O}_{2} \cdot-$ contents of native accessions were significantly higher than those of introduced cultivars

231 in spring and early summer. A maximum production of $\mathrm{H}_{2} \mathrm{O}_{2}$ and $\mathrm{O}_{2} \cdot{ }^{-}$was observed in ' $\mathrm{Hpsp}$ ' in

232 May and June, which was surpassed by 'Hpsi' in summer and autumn. The lowest $\mathrm{H}_{2} \mathrm{O}_{2}$ and $\mathrm{O}_{2}$-'

233 contents were observed in 'Mid'. However, it was statistically similar to those in 'Hpp', 'Moo'

234 or 'Blu', from May to July but notably lower in the rest of the experimental period (Jul.- Oct.).

235 MDA content varied significantly among species with changing temperatures (Fig. 3D). The

236 MDA concentration in all tested accessions was lower in spring, increasing in summer while

237 declining in autumn. Among the entries, the maximum MDA was observed in 'Mid' in early

238 spring, which was similar to 'Hpp'. In summer and late autumn, the highest MDA concentration

was noted for 'Blu' which was similar to that for 'Moo' and 'Hpp' while the lowest was

240 observed in 'Hpsi'. The Chl content in all tested accessions was also significantly affected by

241 seasonal temperatures (Fig. 3C). The highest Chl content was observed in 'Hpsp' in early spring,

242 which decreased in summer and recovered in autumn. Chl content in 'Mid' performed similar

243 tothat in 'Hpp'. Chl content in 'Blu' was distinctly lower in early spring than that in other entries

244 while was similar to that in 'Moo' in summer and autumn. It was also noted that Chl content in

245 'Moo' and 'Hpp' was similar throughout the experiment. 


\section{SOD, CAT, POD, and GSH activity}

247 SOD, CAT, POD, and GSH activities are presented in Figure 4. The SOD activity showed an

248 increasing trend with rising temperature from spring to summer and then declining from autumn

249 (Fig. 4A). The highest SOD activity was observed in 'Mid' while the lowest was recorded in 250 native 'Hpsp' regardless of the seasonal temperatures. The SOD activity in 'Hpp' was 251 statistically similar to that in 'Mid' and 'Moo' in late summer and autumn;similar to that in 252 'Moo' and 'Blu' in early summer while higher than that in 'Hpsi' and 'Hpsp' for the 253 experimental duration. The CAT activity varied significantly among the accessions, but, with no 254 effect of seasonal temperatures (Fig. 4B). The highest CAT activity was observed in 'Mid' which 255 was similar to that in 'Hpsi', so were in 'Moo' and 'Hpp' across the seasons. The lowest CAT 256 activity was observed in 'Hpsp' in spring and autumn. The POD activity was lower in spring 257 while increased with temperatures in summer (Fig. 4C). The Maximum POD ativity was 258 observed in 'Hpp' in all seasons. The POD activity observed for 'Mid' was comparable to 'Hpp' 259 for the experimental duration except in May, when it was slightly low. 'Hpsp' showed the lowest 260 POD activity followed by 'Hpsi'. Similarly, 'Hpp' showed a GSH activity comparable to 'Mid' 261 in early summer and autumn, which was clearly higher than 'Hpsi' and 'Hpsp' but similar to 262 'Moo' and 'Blu'. A lower GSH activity was detected in 'Hpsp' regardless of seasonal 263 temperatures (Fig. 4D).

\section{TSP, TSS, Proline and AsA content}

265 Significant variations $(\mathrm{P}<0.05)$ in TSP, TSS, Proline and AsA content among Poa accessions 266 under changing seasonal temperatures (Fig. 5). 'Hpp' had a TSP content similar to 'Mid' for 267 most of the experimental period except late summer, when 'Hpp' and 'Hpsi' were higher than 268 'Mid' (Fig. 5A). 'Moo' performed similar to 'Mid' and 'Hpp' in spring and early summer, but 
269 lower in late summer and autumn, which were however similar to 'Hpsp'. and 'Blu'. The TSS

270 content also increased with rising temperatures from spring to summer and then declined in

271 autumn (Fig. 5B). 'Mid' produced the maximum TSS, which was similar to 'Hpp' throughout

272 the experiment except late summer when 'Hpp' was distinctly greater than 'Mid'. 'Blu' was

273 comparable to 'Moo' and 'Hpp' across all the seasons. The lowest TSS production was observed

274 in 'Hpsi'. The accessions varied significantly in proline content with changing temperatures from

275 spring to autumn (Fig. 5 C). Proline concentration increased in 'Mid', 'Moo', or 'Hpp' more than

276 other individual Poa entries. The performance among entries was mostly indistinguishable in

277 spring and early summers but onward, 'Hpsi' and 'Hpsp' lost its ability to produce proline and

278 showed the lowest proline concentration. The AsA content differed significantly among the

279 accessions (Fig 5D). An increase in AsA content was more prominent in 'Mid' followed by 'Hpp'

280 from spring to summer. In spring, the AsA produced by 'Hpp', 'Mid', 'Moo' or 'Blu' was

281 roughly the same, but from July to October, maximum AsA was detected in 'Mid' followed by

282 'Hpp', 'Moo' and 'Blu'. The lowest AsA concentration was observed in 'Hpsp'.

\section{DISCUSSION}

284 Heat stress can adversely affect the growth of cool-season turfgrasses and then reduce the turf quality in Heilongjiang, China. We observed significant variabilities among Poa accessions for growth, TQ, and turf color during the summer season. For both native and introduced accessions, TQ, color, coverage and growth rate began to drop with rising temperatures in summer, in comparison with those in early spring and late autumn (Tables 1 and 2), but the variations of thermo-tolerance varied with accessions, indicating that heat resistance and adaptation of these grasses were species-specific. Compared with introduced cultivars, native 'Hpp' performed well, was equal to 'Mid' and 'Moo' for resistance to heat stress in both summers of year 2017 and 
292 2018; and was more heat-tolerant than 'Blu'. 'Hpsi' and 'Hpsp' responded differently, subject to

293 certain physiological and morphological parameters and seasons. These accessions differ in

294 chromosome numbers and ploidies (Fig. 2).

295 'Hpsp' and 'Hpsi' were detected to be tetraploids ( $2 \mathrm{n}=4 \mathrm{x}=28)$; collections of Kentucky bluegrass

296 were anisopolyploids with chromosome numbers of 49 (or 7x), 63 (or 9x), 77 (or 11x) and 49 (or

297 7x), respectively, corresponding to 'Hpp', 'Mid', 'Moo' and 'Blu', hence these accessions are

298 categorized to specific biological species in Poa genus. Correlations between heat stress and

299 chromosome numbers in Poa are unknown, although a previous study mentioned that polyploidy

300 confers a selective advantage under stressful or changing environmental conditions (Van de Peer

301 et al., 2017). Using QTL and bio-omics techniques to reveal the relationship between ploidy and

302 heat resistance of Poa could be of a great significance (Estelle et al., 2021). Interestingly, species

303 'Hpsp' had characters showing that mature seeds shed naturally from panicles onto ground in

304 June; and that these seeds remained dormant in summer, which led to no growth, fading on turf

305 color, and nearly no turf coverage during July and August. However, after summer, 'Hpsp'

306 recovered from dormancy, seeds started germination and tillers developed, with unique dark

307 green color in September and October. These attributes of 'Hpsp' should be useful in repairing

308 damaged environments or for alternative seasonal greenness with lower input. Compared with

309 'Hpsp', 'Hpsi' did not possess these characteristics in summer, but displayed a poorer turf

310 quality than others.

311 Avoiding leaf senescence is critical in maintaining visual turf quality under heat stress.

312 Chlorophyll is an important leaf senescence indicator of heat stress, which reduces the turf

313 quality. A previous study indicated that heat stress leads to reductions in the content of Chl in

314 Kentucky bluegrass that could be associated with the production of reactive oxygen species 
315 (ROS) in response to heat stress (He \& Huang, 2010). Heat stress induces ROS including $\mathrm{H}_{2} \mathrm{O}_{2}$,

$316 \mathrm{O}_{2}^{--}, \mathrm{HO}^{-}, \mathrm{O}_{2}{ }^{1}$, which are partially reduced forms of atmospheric oxygen $\left(\mathrm{O}_{2}^{--}\right)$, and lead to

317 oxidative destruction of cell and pigment breakdown (Mitter, 2002; Abraham et al., 2004; Bita

318 \& Gerats, 2013; Yang et al., 2014). To minimize the oxidative damage under heat stress, plants

319 use antioxidants to dispose of ROS, including enzymatic and nonenzymatic constituents (Bowler

320 et al., 1992; $\mathrm{Xu}$ et al., 2006; Du et al., 2009). $\mathrm{H}_{2} \mathrm{O}_{2}, \mathrm{O}_{2}{ }^{-}$and MDA as ROS representatives and

321 some ROS-Scavenging enzymes including SOD, POD, CAT and GSH were investigated in 2017

322 and 2018 for evaluating heat-resistant ability and potential of selected accessions. We observed

323 that $\mathrm{H}_{2} \mathrm{O}_{2}, \mathrm{O}_{2}^{-}$and MDA increased in all accessions with rising temperatures in summer (Fig.

324 3A, B, D). However, Kentucky bluegrass 'Hpp', 'Mid', 'Moo' and 'Blu' exhibited a lower

325 content of $\mathrm{H}_{2} \mathrm{O}_{2}, \mathrm{O}_{2}^{-}$and MDA than 'Hpsi' and 'Hpsp' in June, or than 'Hpsi' in July and

326 August. On the contrary, ROS scavenging enzymes activities of SOD, POD, CAT and GSH were

327 more vigorous in 'Hpp', 'Mid', 'Moo' and 'Blu' than in 'Hpsi' and 'Hpsp', suggesting that the

328 antioxidant activity of 'Hpp', 'Mid', 'Moo' and 'Blu' was comparatively more than that of 'Hpsi'

329 and 'Hpsp', due to enhanced production of antioxidant (Fig. 4 A, B, C, D). These results are in

330 agreement with Smirnoff (1993) who reported that, plants use ROS scavenging mechanisms to

331 protect cells from oxidative injury, including the activation of antioxidant enzymes to break

332 down $\mathrm{H}_{2} \mathrm{O}_{2}$ to water. We also found that the capacity of oxidative scavenging and accumulation

333 cellular osmolytes such as TSP and proline differed among Kentucky bluegrass accessions,

334 indicating that some physiological responses to heat varied within cultivars. According to Dat et

335 al. (2000), oxidative scavenging capacity differs between plant species and cultivars under

336 varying environmental stress conditions. A positive association between antioxidant activities

337 and heat tolerance have also been documented in other cool-season turfgrass or cultivars in 
338 Kentucky bluegrass (Scandalio, 1993; Zhang \& Schmidt, 2000; Jiang \& Huang, 2001)However,

339 in most cases, native, wild-type 'Hpp' and introduced 'Mid' showed similar performance in heat

340 resistance in terms of plant growth, tiller numbers and physiological response, suggesting that

341 'Hpp' has a great potential to be developed into an excellent variety for commercial use in

342 Heilongjiang, China.

\section{CONCLUSION}

344 Summer heat stress occurs in Heilongjiang of Northeast China even though it is located in the 345 temperate zone; the stress affects cool-season turfgrass growth and turf quality. Exploring native

346 resources of heat-resistant turfgrass is important to urban landscaping nowadays and in the 347 future.

348 Heat stress-related physiological parameters and plant growth performance were studied on three 349 native Poa species 'Hpp', 'Hpsp' and 'Hpsi', in comparison with three introduced Kentucky 350 bluegrass cultivars 'Mid', 'Moo' and 'Blu'. As expected, native 'Hpp' performed mostly 351 comparable to introduced accessions; showed similar characteristics in heat resistance in turf 352 quality, growth rate, tiller numbers and physiological responses such as ROS, osmolytes and 353 anti-oxidant production, suggesting that native 'Hpp' could be used as a new turf resource for 354 further improvement and application under the specific climatic condition of Heilongjiang. 355 'Hpsp' may be used in repairing damaged environments or for alternative seasonal greenness, 356 based on its uniquely dark green color in spring and autumn and its recovery ability from 357 summer. However, 'Hpsi' is not recommended as turf resource for use. 
359 We thank the editor and reviewers for helpful comments. We thank Dr. Xianguang Zhang from

360 Advanta seeds Thailand for his great help to improve the manuscript.

361

362 REFERENCES

363

364

365

366

367

368

369

370

371

372

373

374

375

376

377

378

379

380

Abraham EM, Huang B, Bonos SA, Meyer WA. 2004. Evaluation of drought resistance for Texas bluegrass, Kentucky bluegrass, and their hybrids. Crop Science 44:1746-1753 DOI 10.2135/cropsci2004.1746.

Ábrahám E, Hourton-Cabassa C, Erdei L, Szabados L. 2010. Methods for determination of proline in plants. Methods in Molecular Biology 639:317-331 DOI 10.1007/978-1-60761-702$0 \_20$.

Bita CE, Gerats T. 2013. Plant tolerance to heat in a changing environment: scientific fundamentals and production of heat stress-tolerant crops. Frontiers in Plant Science 4:1-18 DOI 10.3389/fpls.2013.00273.

Bowler C, Montagu MV, Inze D. 1992. Superoxide dismutase and stress tolerance. Annual Review of Plant Physiology and Plant Molecular Biology 43:83-116 DOI 10.1146/annurev.pp. 43.060192.000503.

Bradford MM, 1976. A rapid and sensitive method for the quantitation of microgram quantities of protein utilizing the principle of protein-dye binding. Analytical Biochemistry 72:248-254 DOI 10.1016/0003-2697(76)90527-3.

Bushman BS, Joshi A, Johnson P. 2018. Molecular markers improve breeding efficiency in apomictic Poa pratensis L. Agronomy 8:17 DOI 10.3390/agronomy8020017.

Casler MD, Duncan RR. 2003. Turfgrass Biology, Genetics, and Breeding. David RH. Chapter 
381

382

383

384

385

386

387

388

389

390

391

392

393

394

395

396

397

398

399

400

401

402

2, Kentucky bluegrass. ( $1^{\text {st }}$ ed.). New York: John Wiley \& Sons.

Chen Y, Chen Y, Shi Z, Jin Y, Sun H, Xie FC, Zhang L. 2019. Biosynthesis and signal transduction of ABA, JA, and BRs in response to drought stress of Kentucky bluegrass. International journal of molecular sciences 20:1289 DOI 10.3390 /ijms 20061289.

Chen Y, Zu Y, Liu H, Zhang X, Gao Y. 2008. Advances in studies on germplasm evaluation and genetic improvement of Genus Poa. Acta Horticulturae Sinica 35:1701-1708 DOI 10.3724/SP.J.1005.2008.01083 (in Chinese).

Dat J, Vandenabeele S, Vranova E, Van Montagu M, Inz'e D, Van Breusegem F. 2000. Dual action of the active oxygen species during plant stress responses. Cellular and Molecular Life Sciences 57:779-795 DOI 0.1007/s000180050041.

Du H, Wang Z, Huang B. 2009. Differential responses of warm-season and cool-season turfgrass species to heat stress associated with antioxidant enzyme activity. Journal of the American Society for Horticultural Science 134:417-422 DOI 10.21273/JASHS.134.4.417.

Estelle B, Isidore D, Yolande C, Renaud D, Frédérique B, Anis D, Mohamed Z, Mathilde C. 2021. Genetic diversity of tomato response to heat stress at the QTL and transcriptome levels. The Plant Journal DOI 10.1111/tpj.15379.

Fan J, Zhang W, Amombo E, Hu L, Kjorven JO, Chen L. 2020. Mechanisms of environmental stress tolerance in turfgrass. Agronomy 10:522 DOI 10.3390/agronomy 10040522.

Fry J, Huang B. 2004. Applied Turfgrass Science and Physiology (1 $1^{\text {st }}$ ed.). New York: John Wiley \& Sons.

Giannopolites CN, Ries SK. 1977. Superoxide dismutase occurrence in higher plants. Plant 
403

404

405

406

407

408

409

410

411

412

413

414

415

416

417

418

419

420

421

422

physiology 59:309-314 DOI 10.1104/pp.59.2.309.

Griffith OW. 1980. Determination of glutathione and glutathione disulfide using glutathione reductase and 2-vinylpyridine. Analytical Biochemistry 106:207 DOI 10.1016 /0003-2697 (80)90139-6.

Guo Y, Gao Z, Li L, Wang Y, Zhao H, Hu M, Li M. 2013. Effect of controlled atmospheres with varying $\mathrm{O}_{2} / \mathrm{CO}_{2}$ levels on the postharvest senescence and quality of broccoli (Brassica oleracea L. var. italica) florets. Europe Food Research Technology 237:943-950 DOI 10.1007/s00217-013-2064-0.

Hartley W. 1961. Studies on the origin, evolution and distribution of the Gramineae. IV. The genus Poa L. Australian Journal of Botany 9:152-161 DOI 10.1071/bt9610152.

He YL, Huang BR. 2010. Differential response to heat stress in activities and isozymes of four antioxidant enzymes for two cultivars of Kentucky bluegrass contrasting in heat tolerance. Journal American Society Horticulture Science 135:116-124 DOI 10.1051/fruits/20010006.

Hiscox JD, Israelstam GF. 1979. A method for extraction of chlorophyll from leaf tissue without maceration using dimethyl sulfoxide. Canadian Journal of Botany 57:1332-1334 DOI $10.1139 / \mathrm{b} 79-163$

Honig JA, Averello V, Bonos SA, Meyer WA. 2012. Classification of Kentucky bluegrass (Poa pratensis L.) cultivars and accessions based on microsatellte (simple sequence repeat) markers. HortScience 47:1356-1366 DOI 10.21273/HORTSCI.47.9.1356. 
423 Honig JA, Averello V, Kubik C, Vaiciunas J, Bushman BS, Bonos SA, Meyer WA. 2018. An

424 update on the classification of Kentucky bluegrass cultivars and accessions based on

425 microsatellte (SSR) markers. Crop Science 58:1776-1787 DOI 10.2135/cropsci2017.11.0689.

426

427

Jiang Y, Huang B. 2001. Drought and heat stress injury to two cool-season turfgrasses in 428 relation to antioxidant metabolism and lipid peroxidation. Crop Science 41:436-442 DOI

429 10.2135/cropsci2001.412436x.

Johnson RC, Johnson WJ, Golob CT, Nelson MC, Soreng RJ. 2002. Characterization of the 431 USDA Poa pratensis collection using RADP markers and agronomic descriptors. Genetic Resources and Crop Evolution 49:349-361 DOI 10.1023/A: 1020662108929.

Li F, Zhan D, Xu L, Han L, Zhang X. 2014. Antioxidant and hormone responses to heat stress 434 in two Kentucky bluegrass cultivars contrasting in heat tolerance. Journal of the American Society for Horticultural Science 139:587-596 DOI 10.21273/JASHS.139.5.587.

Ma J, Du G, Li X, Zhang C, Guo J. 2015. A major locus controlling malondialdehyde content under water stress is associated with Fusarium crown rot resistance in wheat. Molecular Genetics and Genomics, 290:1955-1962 DOI 10.1007/s00438-015-1053-3.

Meyer WA. 1982. Breeding disease-resistant cool-season turfgrass cultivars for the United States. Plant Disease 66:341-344 DOI 10.1094/PD-66-341.

Mitter R, 2002. Oxidative stress, antioxidants and stress tolerance. Trends in Plant Science 442 7:415-410 DOI 10.1016/S1360-1385(02)02312-9. 
443 Said M, Holušová K, Farkas A, Ivanizs L, Gaál E, Cápal P, Abrouk M, Martis-Thiele M,

444 Kalapos B, Bartoš J, Friebe B, Dolezel J, Istvan Molnár. 2021. Development of DNA

445 Markers From Physically Mapped Loci in Aegilops comosa and Aegilops umbellulata Using

446 Single-Gene FISH and Chromosome Sequences. Frontiers in Plant Science 12:689031 DOI

$447 \quad 10.3389 /$ fpls.2021.689031.

448

Saud S, Fahad S, Cui G, Chen Y, Anwar S. 2020. Determining nitrogen isotopes

discrimination under drought stress on enzymatic activities, nitrogen isotope abundance and

450 water contents of Kentucky bluegrass. Scientific Reports 10:641510 DOI 10.1038/s41598-

451 020-63548-w.

452

Saud S, Li X, Chen Y, Zhang L, Fahad S, Hussain S, Sadiq A, Chen Y. 2014. Silicon 453 application increases drought tolerance of Kentucky Bluegrass by improving plant water 454 relationsand morphophysiological functions. The Scientific World Journal 2014:1-10. DOI 455 $10.1155 / 2014 / 368694$.

456

Scandalio JG. 1993. Oxygen stress and superoxide dismutase. Plant Physiology 101:7-12. DOI 457 10.1104/pp.101.1.7.

Shortell RR, Dickson WK, Park BS, Bara RF, Smith DA, Wilson MM, Lawson TJ, Clark J, 459 Bonos SA, Murphy JA, Funk CR, Meyer WA. 2004. Performance of Kentucky bluegrass 460 cultivars and selections in New Jersey turf trials. Rutgers Turfgrass Proceedings of the New Jersey Expo 7-9.

462

Smirnoff N. 1993. The role of active oxygen in the response of plants to water deficit and 463 desiccation. New Phytologist 125: 27-58 DOI 10.1111/j.1469-8137.1993.tb03863.x.

Soreng RG. 1990. Chloroplast DNA phylogeneties and biogeography in a reticulating group: 
Speckmann GJ, Dijk GE. 1972. Chromosome number and plant morphology in some ecotypes of Poa pratensis L. Euphytica 21:171-180 DOI 10.1007/bf00036757.

Tian M, Gu Q, Zhu M. 2003. The involvement of hydrogen peroxide and antioxidant enzymes in the process of shoot organogenesis of strawberry callus. Plant Science 165:701-707 DOI 10.1016/S0168-9452(03)00224-3.

Turgeon AJ. 2008. Turfgrass Management $\left(8^{\text {th }}\right.$ ed.). Pearson Prentice Hall Press, USA.

Van de Peer Yves; Ashman TiaLynn; Soltis Pamela S; Soltis Douglas E. 2021. Polyploidy: an evolutionary and ecological force in stressful times. The Plant Cell 33:11-26 DOI 10.1093/PLCELL/KOAA015.

Van de Peer Y, Mizrachi E, Marchal K. 2017. The evolutionary significance of polyploidy. Nature Reviews Genetics 18:411-424 DOI 10.1038/nrg.2017.26.

Wang J, Yuan B, Xu Y, Huang B. 2018. Differential responses of amino acids and soluble proteins to heat stress associated with genetic variations in heat tolerance for hard fescue. Journal of the American Society for Horticultural Science 143:45-55 DOI 10.21273/ JASHS04246-17.

Wei C, Cui Q, Zhang XQ, Zhao YQ, Jia GX. 2016. Three P5CS genes including a novel one from Lilium regale play distinct roles in osmotic, drought and salt stress tolerance. Journal of Plant Biology 59:456-466 DOI 10.1007/s12374-016-0189-y.

Xu S, Li J, Zhang X, Wei H, Cui L. 2006. Effects of heat acclimation pretreatment on changes of membrane lipid peroxidation, antioxidant metabolites, and ultrastructure of chloroplasts in 
$488 \quad 56: 274-285$ DOI 10.1016/j.envexpbot.2005.03.002.

489 Yang Z, Miao Y, Yu J, Liu J, Huang B. 2014. Differential growth and physiological responses 490 to heat stress between two annual and two perennial cool-season turfgrasses. Scientia $491 \quad$ Horticulturae 170: 75-81 DOI 10.1016/j.scienta.2014.02.005.

492 Zhang J, Shi Y, Zhang X, Du H, Xu B, Huang B. 2017. Melatonin suppression of heat493 induced leaf senescence involves changes in abscisic acid and cytokinin biosynthesis and 494 signaling pathways in perennial ryegrass (Lolium perenne L.). Environmental and 495 Experimental Botany 138: 36-45 DOI 10.1016/j.envexpbot.2017.02.012.

496 Zhang X, Schmidt RE. 2000. Hormone-containing products' impact on antioxidant status of tall 497 fescue and creeping bentgrass subjected to drought. Crop Science 40:1344-1349 DOI $498 \quad 10.2135 /$ cropsci2000.4051344x. 
Figure 1

Figure $1(\mathrm{~A})$ Total monthly precipitation $(\mathrm{mm})$ and $(\mathrm{B})$ mean monthly temperature $\left({ }^{\circ} \mathrm{C}\right)$ and 30-yr historical average for Harbin, China, 2017and 2018. Weather data was obtained from Harbin Meteorological Bureau, Heilongjiang, China.
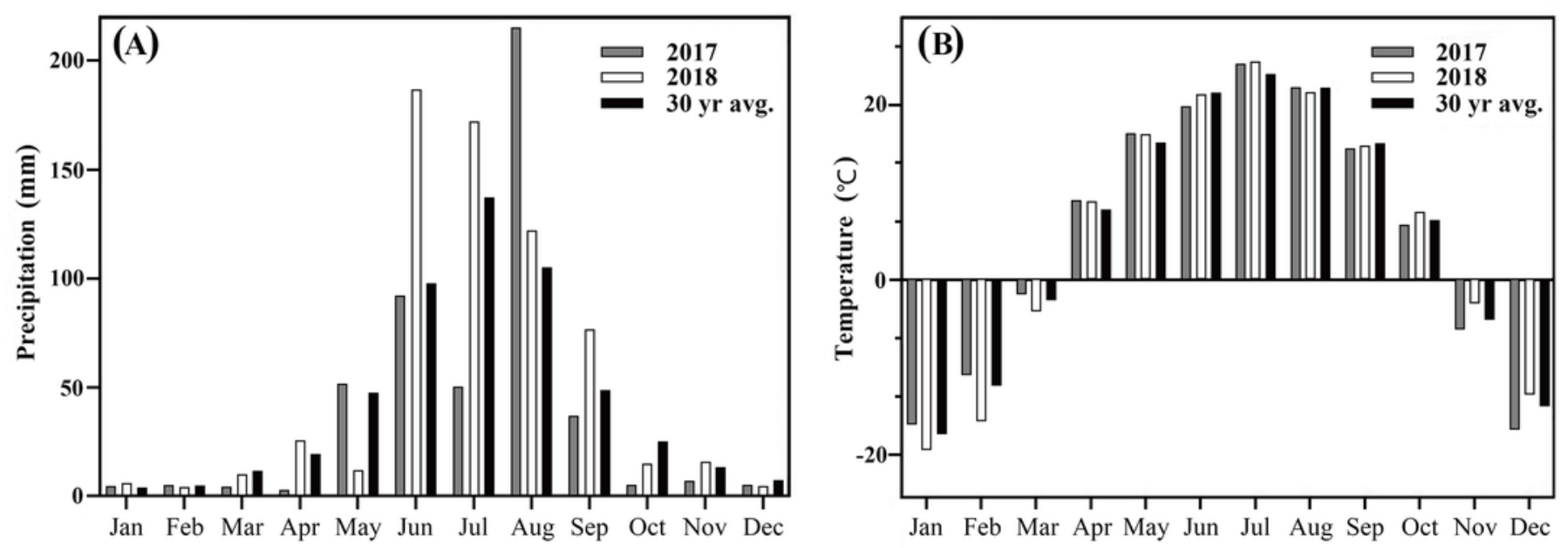


\section{Figure 2}

Figure 2 (A) Metaphase chromosomes of 'Hpp', 2n =7x=49; (B) Metaphase chromosomes of 'Hpsi', $2 \mathrm{n}=4 \mathrm{x}=28$; (C) Metaphase chromosomes of 'Hpsp', $2 \mathrm{n}=4 \mathrm{x}$ = 28; (D) Metaphase chromosomes of 'Blu', $2 n=7 x=49$;

(E) Metaphase chromosomes of 'Moo', $2 n=11 x=77$; (F) Metaphase chromosomes of 'Mid', $2 \mathrm{n}=9 \mathrm{x}=63 ; \mathrm{Hpp}=$ Poa pratensis; Hpsi = P. sibirica; $\mathrm{Hpsp}=$ P. sphondylodes; Mid $=$ Midnight; Moo = Moonlight; Blu = BlueChip.

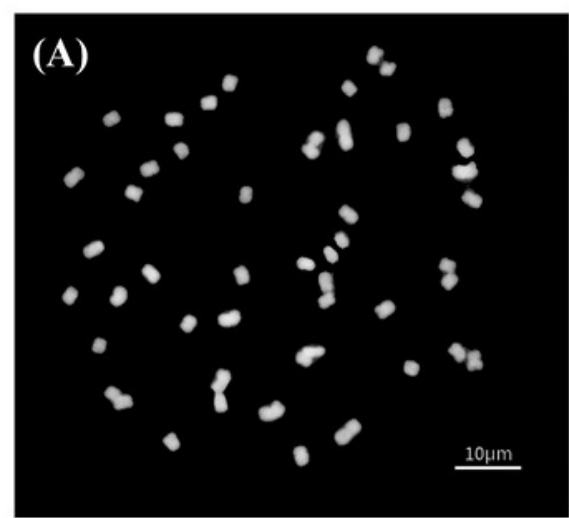

Poa pratensis (Hpp)

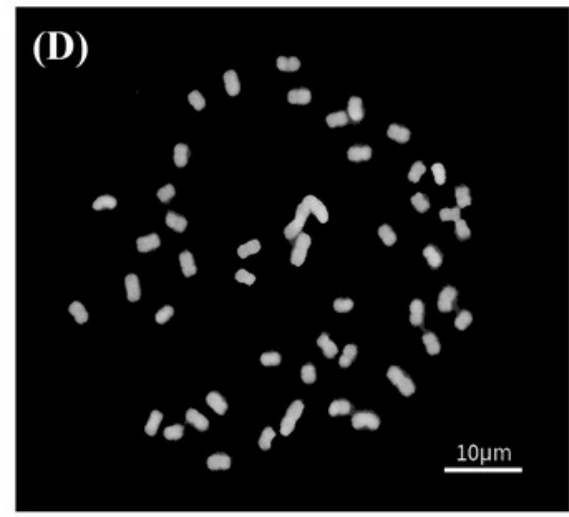

Poa pratensis (Blu)

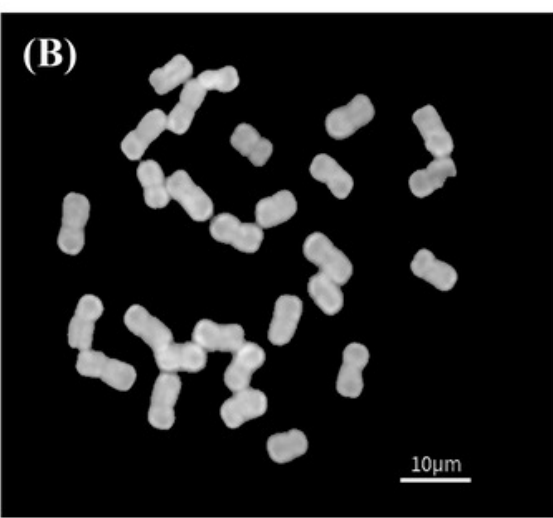

Poa sibirica (Hpsi)

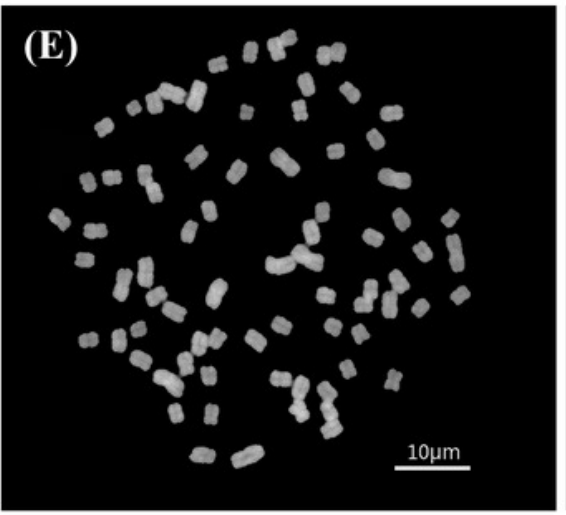

Poa pratensis (Moo)

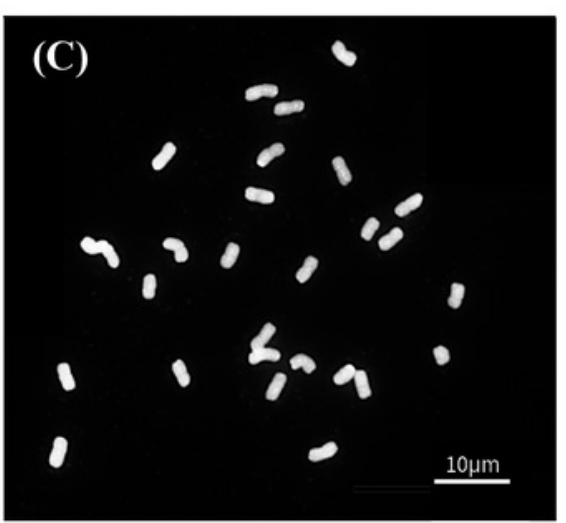

Poa sphondylodes (Hpsp)

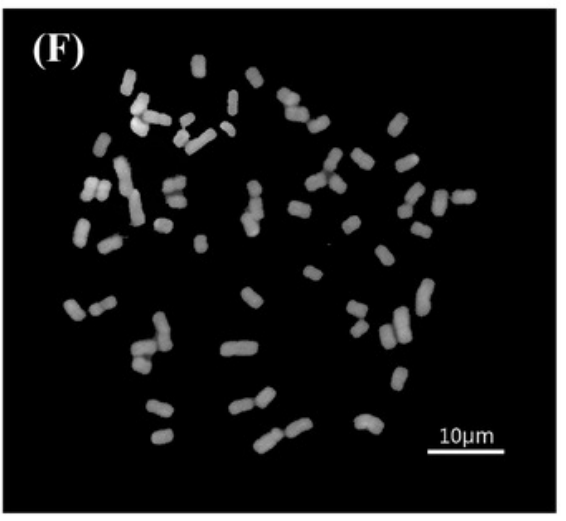

Poa pratensis (Mid) 
Figure 3

Figure 3: The $\mathrm{H}_{2} \mathrm{O}_{2}, \mathrm{O}_{2}$, total chlorophyll and MDA of six Poa accessions during the growing seasons of 2017 to 2018.

Error bars represent $95 \%$ confidence intervals and lowercase letters denote significant differences $(\mathrm{P}<0.05) ; \mathrm{Hpp}=$ Poa pratensis; $\mathrm{Hpsi}=P$. sibirica; $\mathrm{Hpsp}=P$. sphondylodes; Mid $=$ Midnight; Moo = Moonlight; Blu = BlueChip.
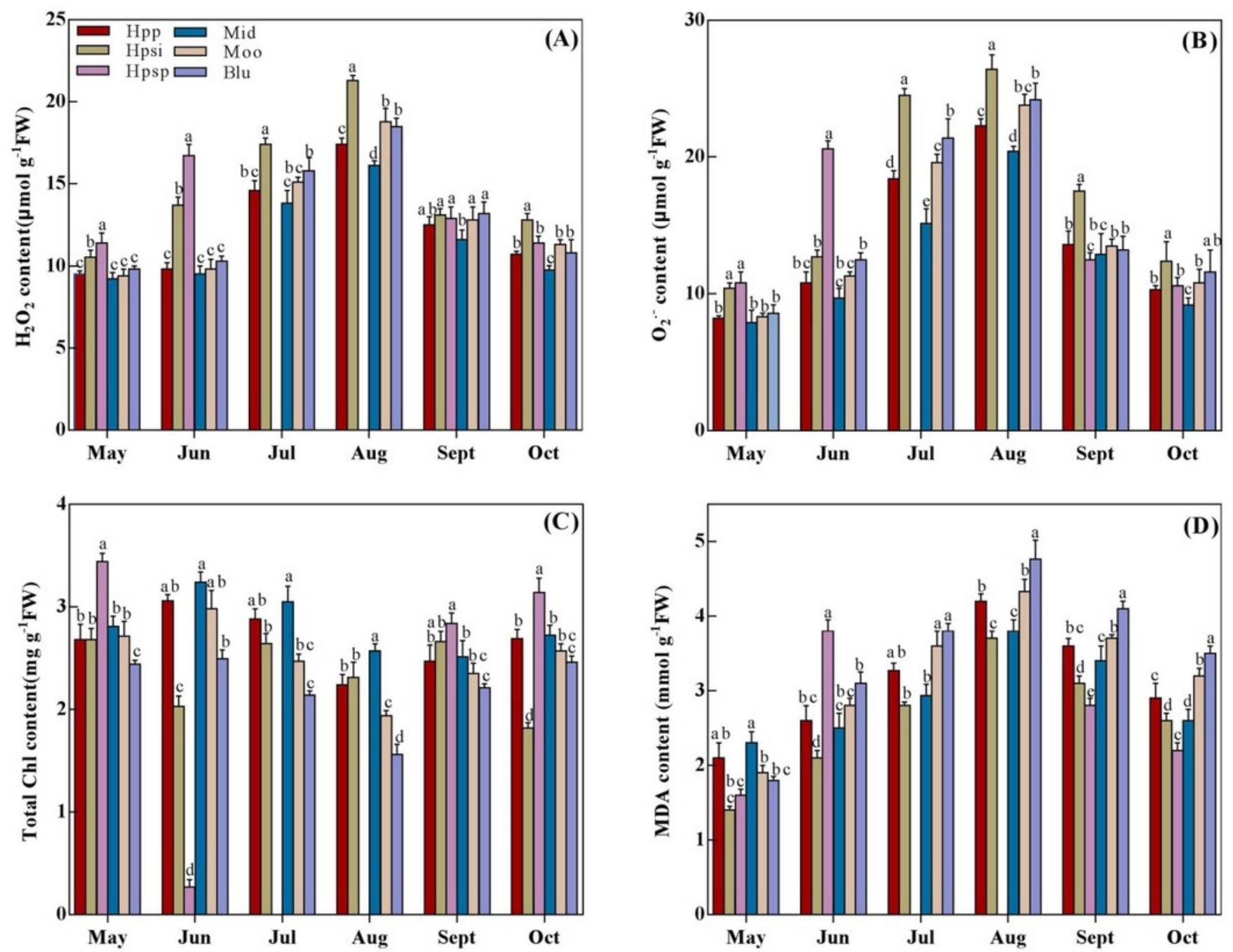
Figure 4

Figure 4: The SOD, CAT, POD, and GSH activity of six Poa accessions during the growing seasons of 2017 to 2018.

Error bars represent 95\% confidence intervals and lowercase letters denote significant differences $(\mathrm{P}<0.05) ; \mathrm{Hpp}=$ Poa pratensis; Hpsi = P. sibirica; Hpsp = P. sphondylodes; Mid $=$ Midnight; Moo = Moonlight; Blu = BlueChip.
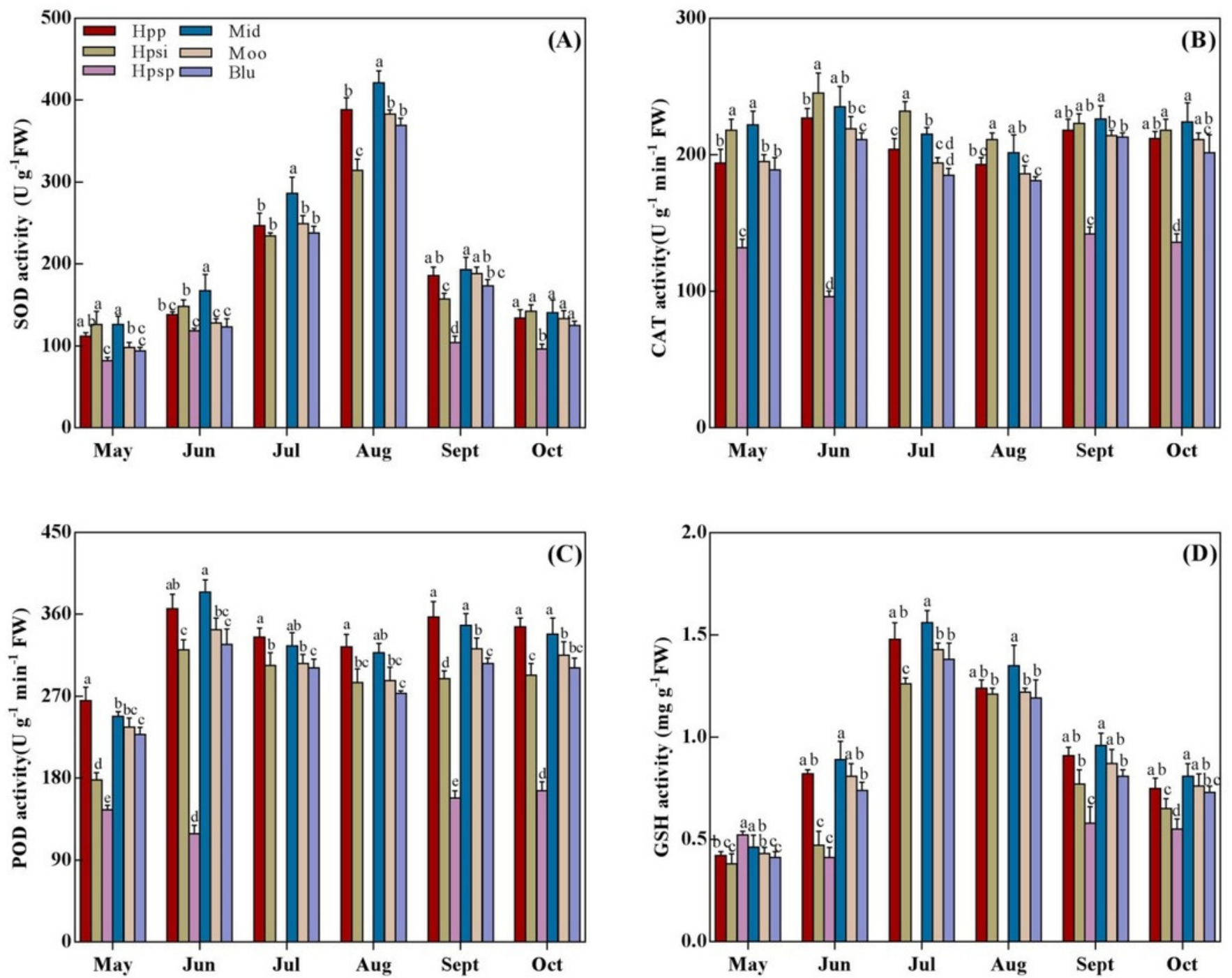
Figure 5

Figure 5: The TSP, TSS, Proline and ASA content of six Poa accessions during the growing seasons of 2017 to 2018.

Error bars represent 95\% confidence intervals and lowercase letters denote significant differences $(\mathrm{P}<0.05) ; \mathrm{Hpp}=$ Poa pratensis; Hpsi $=P$. sibirica; $\mathrm{Hpsp}=P$. sphondylodes; Mid $=$ Midnight; Moo = Moonlight; Blu = BlueChip.
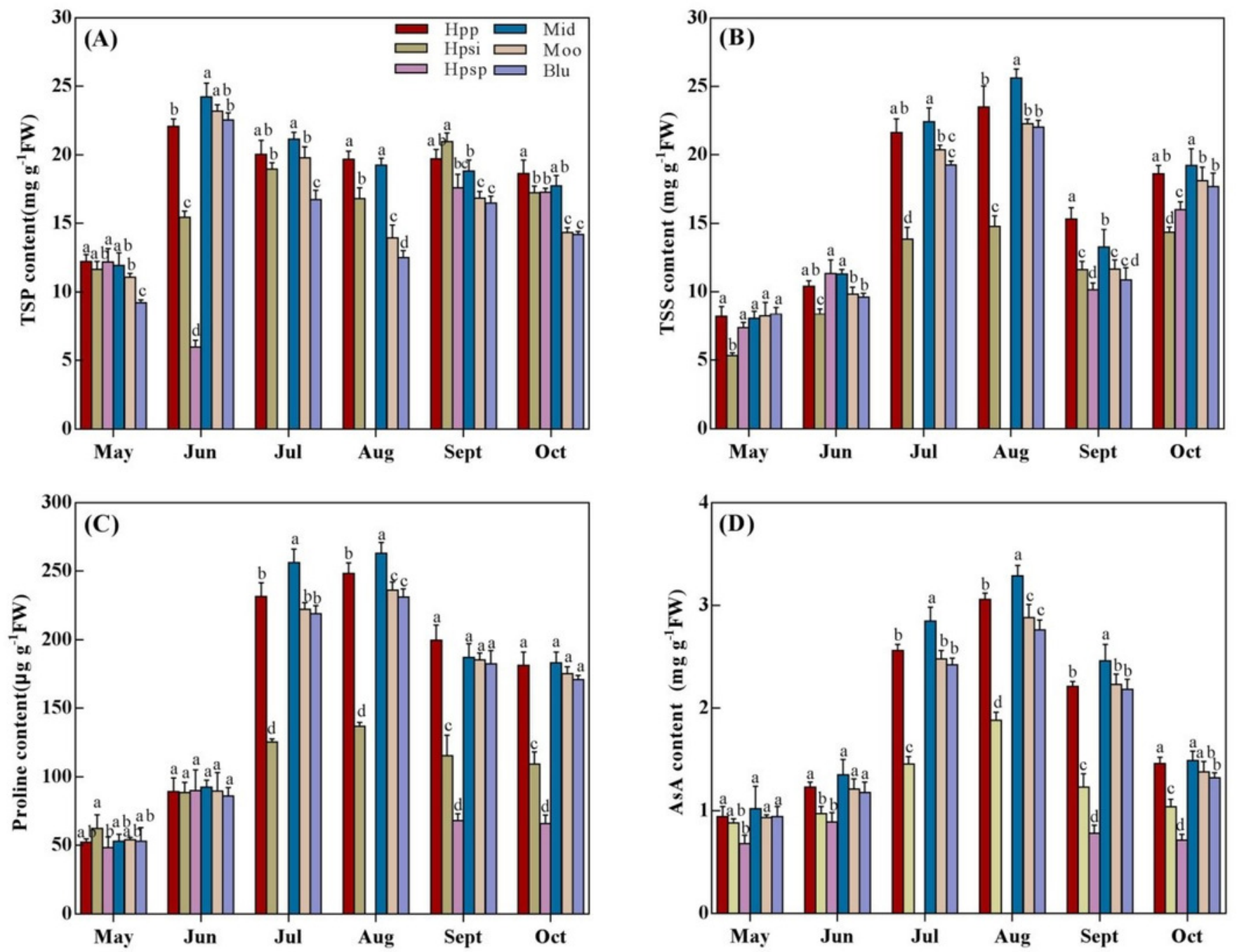


\section{Table $\mathbf{1}$ (on next page)}

The monthly turf quality and color responses of three native Poa species and three introduced cultivars of Kentucky bluegrass during the 2017 and 2018 growing seasons in Harbin, China.

Note: $\mathrm{Hpp}=$ Poa pratensis; $\mathrm{Hpsi}=$ P. sibirica; $\mathrm{Hpsp}=$ P. sphondylodes; Mid = Midnight; Moo $=$ Moonlight; Blu = BlueChip. Lowercase denotes significant differences within each vertical row for dif-ferent entries ( $P<0.05)$; Upper case means significant differences within each horizontal row for different months in one entry $(P<0.05)$. Same as the following table 2 and 3. 


\begin{tabular}{|c|c|c|c|c|c|c|c|c|c|c|c|c|}
\hline \multirow[b]{2}{*}{ Entries } & \multicolumn{6}{|c|}{ Two years average turfgrass quality (1-9) } & \multicolumn{6}{|c|}{ Two years average turf color (1-9) } \\
\hline & May & Jun & Jul & Aug & Sept & Oct & May & Jun & Jul & Aug & Sept & Oct \\
\hline Hpp & $7.5 \mathrm{abA}$ & $7.2 \mathrm{bB}$ & $6.8 \mathrm{abC}$ & $6.5 \mathrm{abC}$ & $7.0 \mathrm{bBC}$ & $7.8 \mathrm{aA}$ & $8.5 \mathrm{aA}$ & $8.0 \mathrm{aAB}$ & 7.5abB & $6.8 \mathrm{aC}$ & $7.5 \mathrm{bB}$ & $8.2 \mathrm{abA}$ \\
\hline Hpsi & $6.4 \mathrm{cA}$ & $6.0 \mathrm{dA}$ & $5.4 \mathrm{cB}$ & $5.0 \mathrm{cB}$ & $5.5 \mathrm{cB}$ & $6.2 \mathrm{cA}$ & $6.5 \mathrm{cA}$ & $6.2 \mathrm{cA}$ & $5.5 \mathrm{cB}$ & $5.5 \mathrm{bB}$ & $6.6 \mathrm{dA}$ & $6.8 \mathrm{cA}$ \\
\hline Hpsp & $7.8 \mathrm{abA}$ & $4.0 \mathrm{eC}$ & $1.0 \mathrm{dC}$ & $1.0 \mathrm{dC}$ & $4.5 \mathrm{dC}$ & $7.0 \mathrm{bB}$ & $8.5 \mathrm{aA}$ & $5.0 \mathrm{~dB}$ & $1.0 \mathrm{dC}$ & $1.0 \mathrm{cC}$ & $8.8 \mathrm{aA}$ & $8.6 \mathrm{aA}$ \\
\hline Mid & $8.0 \mathrm{aA}$ & $7.8 \mathrm{aAB}$ & $7.5 \mathrm{aB}$ & $7.0 \mathrm{aC}$ & 7.8aAB & $8.0 \mathrm{aA}$ & $8.5 \mathrm{aA}$ & $8.2 \mathrm{aA}$ & $8.0 \mathrm{aA}$ & $7.0 \mathrm{aB}$ & $7.8 \mathrm{bA}$ & $8.5 \mathrm{aA}$ \\
\hline Moo & $7.2 \mathrm{bA}$ & $7.0 \mathrm{bcAB}$ & $6.5 \mathrm{bBC}$ & $6.0 \mathrm{bC}$ & $7.2 \mathrm{bA}$ & $7.5 \mathrm{aA}$ & $8.0 \mathrm{bA}$ & $7.8 \mathrm{aAB}$ & 7.5abAB & $6.4 \mathrm{abC}$ & $7.4 \mathrm{bcB}$ & $7.8 \mathrm{bAB}$ \\
\hline Blu & $6.8 \mathrm{bcAB}$ & $6.5 \mathrm{cB}$ & $6.0 \mathrm{bC}$ & $5.2 \mathrm{cD}$ & $6.0 \mathrm{cC}$ & $7.0 \mathrm{bA}$ & $8.0 \mathrm{bA}$ & $7.2 \mathrm{bB}$ & $7.0 \mathrm{bB}$ & $5.8 \mathrm{bC}$ & $7.0 \mathrm{cdB}$ & $7.5 \mathrm{bcAB}$ \\
\hline
\end{tabular}

1 


\section{Table 2 (on next page)}

Table 2: The monthly turf coverage and growth rate responses of three native Poa species and three introduced cultivars of Kentucky bluegrass during the 2017 and 2018 growing seasons in Harbin, China. 
Two years average turfgrass growth rate

Two years average turfgrass coverage $(\%)$

\begin{tabular}{|c|c|c|c|c|c|c|c|c|c|c|c|c|}
\hline Entries & May & Jun & Jul & Aug & Sept & Oct & May & Jun & Jul & Aug & Sept & Oct \\
\hline Нpp & $94.4 \mathrm{aAB}$ & 96.4abA & 94.1abAB & $86.4 \mathrm{bC}$ & $90.5 \mathrm{bBC}$ & $93.2 \mathrm{aAB}$ & $11.4 \mathrm{bB}$ & $12.8 \mathrm{bA}$ & $10.4 \mathrm{bB}$ & $8.6 \mathrm{bC}$ & $10.2 \mathrm{bB}$ & $10.8 \mathrm{bcB}$ \\
\hline Hpsi & $85.5 \mathrm{cB}$ & $88.5 \mathrm{cA}$ & $81.6 \mathrm{cD}$ & $83.2 \mathrm{cC}$ & $85.2 \mathrm{bB}$ & $84.7 \mathrm{cB}$ & $17.8 \mathrm{aAB}$ & $18.6 \mathrm{aA}$ & $16.3 \mathrm{aB}$ & $12.5 \mathrm{aD}$ & $13.8 \mathrm{aCD}$ & $14.6 \mathrm{aC}$ \\
\hline Hpsp & $80.6 \mathrm{~dB}$ & $30.6 \mathrm{dC}$ & $5.5 \mathrm{dD}$ & $3.2 \mathrm{dD}$ & $77.6 \mathrm{cB}$ & $88.5 \mathrm{bcA}$ & $4.8 \mathrm{dA}$ & $3.4 \mathrm{~dB}$ & --- & --- & $2.6 \mathrm{dC}$ & $4.6 \mathrm{dA}$ \\
\hline Mid & $96.8 \mathrm{aA}$ & $98.5 \mathrm{aA}$ & $96.2 \mathrm{aA}$ & $90.3 \mathrm{aB}$ & $95.8 \mathrm{aA}$ & $95.5 \mathrm{aA}$ & $17.3 \mathrm{aAB}$ & $18.9 \mathrm{aA}$ & $16.3 \mathrm{aB}$ & $12.7 \mathrm{aD}$ & $14.8 \mathrm{aB}$ & $15.3 \mathrm{aB}$ \\
\hline Moo & $93.5 \mathrm{abA}$ & $94.2 \mathrm{bA}$ & $91.7 \mathrm{abA}$ & $86.5 \mathrm{bC}$ & $89.5 \mathrm{bB}$ & $93.6 \mathrm{aA}$ & $11.2 \mathrm{bcB}$ & $12.5 \mathrm{bA}$ & $9.6 \mathrm{bcC}$ & $8.1 \mathrm{bD}$ & $10.7 \mathrm{bBC}$ & $11.2 \mathrm{bB}$ \\
\hline Blu & $90.3 \mathrm{bA}$ & $90.8 \mathrm{bcA}$ & $88.4 \mathrm{bcB}$ & $84.3 \mathrm{cC}$ & $88.2 \mathrm{bB}$ & $90.4 \mathrm{abA}$ & $9.9 \mathrm{cAB}$ & $10.6 \mathrm{cA}$ & $8.4 \mathrm{cBC}$ & $7.8 \mathrm{bC}$ & $9.1 \mathrm{cB}$ & $9.6 \mathrm{cA}$ \\
\hline
\end{tabular}

2 


\section{Table 3 (on next page)}

Table 3: The tiller number responses of three native Poa species and three introduced cultivars of Kentucky bluegrass during 2017 and 2018 growing seasons in Harbin, China. 


\begin{tabular}{|c|c|c|c|c|c|c|}
\hline \multirow[b]{2}{*}{ Entries } & \multicolumn{6}{|c|}{ Two year average turfgrass tillers } \\
\hline & May & Jun & Jul & Aug & Sept & Oct \\
\hline Hpp & $10.8 \mathrm{bC}$ & $11.9 \mathrm{bB}$ & $12.8 \mathrm{abAB}$ & $11.9 \mathrm{aB}$ & $12.4 \mathrm{bAB}$ & $12.9 \mathrm{bA}$ \\
\hline Hpsi & $7.3 \mathrm{dC}$ & $9.0 \mathrm{cA}$ & $9.5 \mathrm{cA}$ & $6.9 \mathrm{cC}$ & $8.3 \mathrm{~dB}$ & $8.9 \mathrm{cAB}$ \\
\hline Hpsp & $5.4 \mathrm{eAB}$ & $6.1 \mathrm{dA}$ & $1.7 \mathrm{dD}$ & $1.3 \mathrm{dD}$ & $2.7 \mathrm{eC}$ & $5.1 \mathrm{~dB}$ \\
\hline Mid & $11.9 \mathrm{aD}$ & $12.9 \mathrm{aBC}$ & $13.2 \mathrm{aAB}$ & $12.5 \mathrm{aCD}$ & $13.4 \mathrm{aAB}$ & $14.0 \mathrm{aA}$ \\
\hline Moo & $10.2 \mathrm{bcB}$ & $12.1 \mathrm{abA}$ & $12.6 \mathrm{abA}$ & $10.8 \mathrm{bB}$ & $12.1 \mathrm{bA}$ & $12.5 \mathrm{bA}$ \\
\hline Blu & $9.7 \mathrm{cC}$ & $11.4 \mathrm{bAB}$ & $12.2 \mathrm{bA}$ & $10.4 \mathrm{bC}$ & $11.3 \mathrm{cB}$ & $12.2 \mathrm{bA}$ \\
\hline
\end{tabular}

2 